\title{
KETERAMPILAN PROSES SAINS, KETERAMPILAN SOSIAL, KETERAMPILAN PSIKOMOTORIK, SERTA PENGUASAAN KONSEP SISWA SMA MELALUI PEMBELAJARAN BERBASIS INKUIRI
}

\author{
Rahmat Rasmawan \\ Dosen Program Studi Pendidikan Kimia FKIP Untan \\ Email: rahmatfkip@gmail.com
}

\begin{abstract}
The purpose of this research to describe scientific proccess skills, social skill, psychomotor skill and mastery concept student through inquiry based learning. Type of this research is descriptive with this subject 34 students of Science at 11th grade of SMAN 7 Pontianak. The measured of scientific procces skill by performance assessment test. The measured of the social skill by observation sheet of the social skill. The measured of the psychomotor skill by performance assessment test. The measured of the understanding concept by essay test about concept. The result shows that scientific proccess skills, social skill, psychomotor skill and mastery concept are 100\%, 100\%, $87 \%$ and $78 \%$ respectively. Based on the result, we can conclude that inquiry based learning could evolved scientific proccess skills and social skill students, trained to use tools of lab work and make students to understanding concept.
\end{abstract}

Key Word: Scientific Proccess Skills, Social Skill, Psychomotor Skill, Mastery Concept, Inquiry Based Learning.

Pemberlakuan Kurikulum Tingkat Satuan Pendidikan (KTSP) menuntut adanya perubahan struktur materi, orientasi pembelajaran dan penilaian. Rekonstruksi materi kimia di SMA memuat lingkup materi ajar yang mencakup kemampuan prosedural dan konseptual. Substansi dari kemampuan prosedural meliputi keterampilan proses sains dan sikap ilmiah (inkuiri sains). Selanjutnya, kemampuan konseptual yang dimuat pada bahan kajian kimia adalah pemahaman konsep serta penerapannya yang mencakup komposisi, struktur dan sifat, perubahan, dinamika, dan energitika zat (Depdiknas, 2006).
Tujuan diajarkannya mata pelajaran kimia di SMA/MA menekankan bahwa dalam proses pembelajaran harus dapat menumbuhkan kemampuan berpikir, bekerja dan bersikap ilmiah serta kemampuan berkomunikasi sebagai aspek penting dari kecakapan hidup (Depdiknas, 2006). Dengan demikian pembelajaran kimia tidak hanya didominasi oleh penguasaan konsep belaka tetapi aspek keterampilan khususnya keterampilan proses, afektif dan psikomotorik siswa perlu dikembangkan pada proses pembelajarannya.

Hasil observasi terhadap proses pembelajaran kimia pada salah 
satu guru kimia kelas XI IPA SMA Negeri 7 Pontianak dapat disimpulkan bahwa (1) proses pembelajaran yang sering dilakukan guru dalam pembelajaran kimia adalah menyampaikan konsep yang harus dikuasai siswa, (2) guru jarang mengaitkan materi pelajaran kimia dengan kehidupan sehari-hari siswa dan (3) bentuk tes yang biasa dilatihkan guru adalah penyelesaian masalah algoritmik yang biasa dijawab melalui suatu prosedur yang telah baku atau keahlian kognitif tingkat rendah. Dengan demikian disimpulkan kecenderungan yang terjadi adalah guru satu-satunya pusat informasi tentang materi pembelajaran dan kurang melibatkan peran aktif siswa dalam proses pembelajarannya. Hal ini tergambar dari guru hanya menyampaikan materi yang akan dipelajari dan tidak membimbing siswa menemukan konsep yang dipelajari. Konsekuensi yang dapat timbul dari proses pembelajaran yang demikian terhadap kemampuan berpikir siswa hanya sebatas lower order thingking (Jazadi, 2005), keterampilan yang diperoleh siswa hanya sebatas pengumpulan informasi dan mengingatnya (Bruner, dalam Slavin 2006) dan yang lebih parah lagi dapat menenggelamkan kreativitas siswa (Holbrook, 2005).

Pola pembelajaran kimia yang selama ini dilakukan perlu segera diperbaiki. Hendaknya pembelajaran kimia dirancang dengan memperhatikan tujuan, karakteristik materi yang diajarkan, kemampuan siswa, dan sumber belajar yang tersedia. Siswa diberi kesempatan untuk menggali pemahaman, mengembangkan kemampuan berpikir dan keterampilan proses sains termasuk penyelidikan ilmiah dan penyelesaian masalah. Kemendikbud (2013) menyatakan tujuan umum mata pelajaran kimia dimaksudkan untuk memperoleh kompetensi lanjut ilmu kimia serta membudayakan berpikir ilmiah secara kritis, kreatif, dan mandiri. Dengan demikian, guru harus memberikan kesempatan kepada peserta didik untuk dapat: (a) memahami, merancang, memecahkan masalah, mengetahui bagaimana cara dan mengapa melakukan, dan (b) menganalisis, memonitor, mengevaluasi dan mengembangkan pemahaman konsepnya (Permendiknas nomor 41 tahun 2007).

Untuk mengembangkan kemampuan pemahaman konsep (penguasaan konsep) keterampilan sosial (afektif), keterampilan penggunaan alat (psikomotorik), dan keterampilan proses sains maka siswa diberi kesempatan untuk menggali pemahaman, mengembangkan kemampuan berpikir dan keterampilan proses sains termasuk penyelidikan ilmiah dan penyelesaian masalah. Kemendikbud (2013) menyatakan tujuan umum mata pelajaran kimia dimaksudkan untuk memperoleh kompetensi lanjut ilmu kimia serta membudayakan berpikir ilmiah secara kritis, kreatif dan mandiri. Dengan demikian, guru harus memberikan kesempatan kepada peserta didik untuk dapat memahami, merancang, memecahkan masalah, mengetahui bagaimana cara dan mengapa melakukan, menganalisis, memonitor, mengevaluasi, mengkomunikasikan dan mengembangkan pemahaman 
konsepnya (Permendiknas nomor 41 tahun 2007).

\begin{tabular}{lrr}
\multicolumn{1}{c}{ Salah } & \multicolumn{1}{c}{ satu } & model \\
pembelajaran & yang & dapat \\
meningkatkan & pemahaman & konsep, \\
pembentukan & keterampilan & sosial, \\
penggunaan alat (psikomotorik) & serta \\
keterampilan & proses & sains \\
pembelajaran & berbasis & inkuiri \\
Menurut Wenning & $(2004)$ \\
pembelajaran berbasis inkuiri adalah \\
model pembelajaran yang \\
menitikberatkan pada
\end{tabular} membangun pengetahuan dari pengalaman-pengalaman belajar yang menggunakan urutan langkah atau prosedur sehingga dapat membimbing siswa menarik kesimpulan yang benar dan valid. Dalam mencapai kesimpulan yang benar, siswa dihadapkan pada aktivitas merancang, memecahkan masalah, mengetahui bagaimana cara dan mengapa melakukan percobaan, menganalisis data, memonitor, mengevaluasi, dan mengkomunikasikan hasil yang diperoleh, sehingga dapat mengembangkan pemahaman konsepnya (Bruner, dalam Slavin 2006).

Menurut Arends (2012) model pembelajaran berbasis inkuiri memiliki enam fase yang berhubungan langsung dengan keterampilan proses. Pada fase 1, siswa merumuskan masalah yang akan dipecahkan atau diselidiki. Pada fase 2, siswa merumuskan hipotesis berdasarkan hasil sintesis literatureliteratur yang relevan atau terkait dengan rumusan masalah yang dibuat. Pada fase 3, siswa mengumpulkan data atau informasi untuk menjawab permasalahan baik dari kajian konsep dan melalui percobaan. Pada fase 4, siswa memberikan analisis terhadap data yang dikumpulkan. Pada fase 5, siswa menarik kesimpulan dari hasil analisis data. Pada fase 6 (fase akhir), siswa melakukan refleksi terhadap kesimpulan yang dibuat dan membandingkannya dengan hipotesis yang telah siswa rumuskan.

Banyak hasil penelitian yang menunjukkan efektivitas model inkuiri. Hasil penelitian yang dilakukan Lestari, Dantes, dan Sadia (2013) diperoleh hasil bahwa siswa sikap ilmiah siswa yang diajar dengan model inkuiri lebih baik dibandingkan siswa yang diajar dengan model konvensional serta hasil belajar siswa yang diajar dengan model inkuiri lebih baik daripada siswa yang diajar dengan model konvensional. Balim (2009) mengemukakan bahwa hasil belajar, retensi dan keterampilan proses sains siswa yang diajar dengan model pembelajaran inkuiri lebih baik dibandingkan model konvensional. Potvin, Riopel, Masson, dan Fournier (2010) mengemukakan bahwa penerapan model pembelajaran inkuiri dapat menanggulangi kesalahan memahami konsep atau miskonsepsi siswa. Panasan dan Nuangchalerm (2010) mengemukakan bahwa pembelajaran dengan model inkuiri sangat efektif dan efisien ditinjau dari hasil belajar, keterampilan proses sains dan aktivitas yang mengalami peningkatan. Berdasarkan uraian di atas, peneliti tertarik untuk mendiskripsikan keterampilan proses sains, keterampilan sosial, keterampilan psikomotorik dan penguasaan konsep siswa SMA yang diajar dengan menggunakan model pembelajaran berbasis inkuiri. 


\section{Metode}

Penelitian ini bertujuan untuk mendeskripsikan keterampilan proses sains, keterampilan sosial, keterampilan psikomotorik serta penguasaan konsep siswa yang diajar dengan model pembelajaran berbasis inkuiri. Metode penelitian yang digunakan adalah deskriptif. Subjek dalam penelitian ini adalah siswa kelas XI IPA SMA Negeri 7 Pontianak yang berjumlah 33 siswa. Materi yang digunakan dalam penelitian ini adalah definisi laju reaksi, faktor-faktor yang mempengaruhi laju reaksi serta penentuan orde reaksi.

Alat pengumpul data yang digunakan dalam penelitian ini adalah tes unjuk kerja keterampilan proses sains, lembar observasi pengamatan keterampilan sosial siswa, tes unjuk kerja penggunaan alat dan tes tertulis untuk mengukur penguasaan konsep siswa dalam menyelesaikan soal berbentuk esay. Sebelum digunakan, terlebih dahulu alat pengumpul data divalidasi pakar untuk ditentukan kevalidan serta kelayakan penggunaannya.

Hasil yang diperoleh pada tahap validasi menunjukkan bahwa tes unjuk kerja keterampilan proses sains sesuai dengan indikator yang dirumuskan dan kalimatnya mudah dipahami sehingga valid dan layak digunakan, lembar observasi keterampilan sosial siswa memiliki petunjuk yang jelas sehingga valid dan layak digunakan, tes unjuk kerja penggunaan alat telah sesuai dengan langkah-langkah penggunaannya serta rincian tugas kinerjanya mudah dipahami sehingga valid dan layak digunakan, serta tes tertulis untuk mengukur penguasaan konsep telah sesuai dengan indikator dan bahasa yang digunakan mudah dimengerti dan tidak menimbulkan makna ganda sehingga valid dan layak digunakan.

Data hasil tes penguasaan konsep, keterampilan sosial, keterampilan proses sains dan keterampilan psikomotorik siswa selanjutnya ditentukan ketuntasan tiap-tiap indikator menggunakan proporsi jawaban tiap-tiap indikator yang diujikan dengan rumus:

Proporsi Jawaban $=\frac{\text { shor yang diperoleh indikator }}{\text { shor maksimal indikator }}$

Siswa dikatakatan mengalami ketuntasan tiap indikator yang diujikan memperoleh nilai proporsi jawaban lebih besar atau sama dengan 0,7 .

Ketuntasan individual siswa ditentukan dengan cara:

\begin{tabular}{|l|}
$K I=\frac{\text { Jumlah indikator yang tuntas }}{\text { jumlah seluruh indikator }} \times 100 \%$ \\
Siswa dikatakan mengalami
\end{tabular} ketuntasan individual jika nilai KI yang diperoleh siswa lebih besar atau sama dengan $70 \%$ (sesuai dengan SKBM kelas XI IPA SMA N 7 mata pelajaran kimia yaitu $70 \%$.

\section{Hasil dan Pembahasan}

Berdasarkan hasil penelitian yang dilakukan, didapat ketuntasan untuk keterampilan proses sains, keterampilan sosial, keterampilan psikomotorik dan penguasaan konsep siswa yang ditunjukkan pada Gambar 1.

Pada Gambar 1 dapat dijelaskan sebagai berikut:

1. Pemahaman Konsep Siswa

Dari Gambar 1 dapat diketahui bahwa siswa yang mengalami ketuntasan individual dengan SKBM 70 sebanyak $78 \%$. Dengan demikian terdapat $22 \%$ siswa 


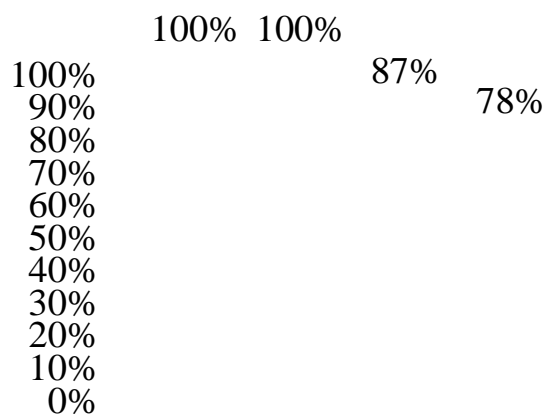

Gambar 1. Persentase ketuntasan

yang belum mengalami ketuntasan individual.Hal ini mengindikasikan bahwa sebagian besar siswa (78\%) dapat menguasai konsep-konsep yang diajar melalui model pembelajaran berbasis inkuiri.

Pemahaman konsep siswa memiliki ketuntasan individual sebesar $78 \%$. Hasil yang didapat menunjukkan bahwa proses pembelajaran dengan menggunakan model pembelajaran berbasis inkuri berhasil membuat siswa memahami konsep yang dipelajari. Menurut Solso (2008) tahap awal pembentukan konsep adalah pada saat siswa merumuskan hipotesis atau strategi yang akan digunakan dalam penyelesaian masalah dan berupaya menemukan sesuatu untuk mendukung hipotesis atau strategi yang akan digunakan tersebut. Selajan dengan itu, Piaget menyatakan bahwa pembuktian secara aktif yang lakukan siswa dapat mendorong siswa merumuskan pengetahuan baru dengan cara memodifikasi, menambahkan karakteristik serta memperbaiki konsep yang telah dipahami sebelumnya (Slavin. 2006).

Siswa yang tidak tuntas secara individual mengindikasikan bahwa tidak semua siswa terlibat secara aktif membangun pengetahuan sehingga dapat memahami konsep dengan baik. Salah satu faktor penyebabnya adalah proses pembelajaran yang dilakukan adalah diskusi kecil yang terdiri dari 5 sampai 6 kelompok dalam menjawab seluruh permasalahanpermasalahan yang diberikan melalui LKS dan masing-masing anggota tidak berkewajiban membuat anggota kelompoknya paham. Orientasi kerja kelompok hanya menitikberatkan terselesainya tugas yang diberikan. Hasil penelitian yang dirangkum oleh Slavin (2006) menunjukkan bahwa diskusi kelompok tidak efektif apabila masing-masing anggotanya tidak dapat mengorganisir dengan baik peran masing-masing anggota kelompok dan kelompok hanya berupaya meyelesaikan tugas yang diberikan tanpa terlibat dalam suatu kontroversi pendapat masingmasing anggotanya. Ketuntasan tiap-tiap indikator dari tes pemahaman konsep siswa disajikan pada Tabel 1.

Dari Tabel 1 dapat diketahui bahwa sebagian besar siswa kesulitan dalam menganalisis data percobaan. Hal ini terlihat dari indikator menganalisis faktor yang dapat mempengaruhi laju reaksi berdasarkan data percobaan dan menganalisis pengaruh peningkat- 
an suhu terhadap laju reaksi. Hal ini mengindikasikan bahwa model pembelajaran berbasis inkuiri yang dilaksanakan belum mengajarkan secara optimal kemampuan menganalisis data hasil percobaan.

Tabel 1. Persentase Kentuntasan Tiap-Tiap Indikator Tes Pemahaman Konsep Siswa.

\begin{tabular}{lcc}
\hline \multicolumn{1}{c}{ Indikator } & \multicolumn{2}{c}{ Ketuntasan(\%) } \\
\hline $\begin{array}{l}\text { Menjelaskan } \\
\text { pengertian laju reaksi. }\end{array}$ & 91 & $\mathrm{~T}$ \\
\hline $\begin{array}{l}\text { Menganalisis data } \\
\text { untuk menentukan } \\
\text { ungkapan laju reaksi. }\end{array}$ & 85 & $\mathrm{~T}$ \\
\hline $\begin{array}{l}\text { Menganalisis grafik } \\
\text { energi aktivasi. }\end{array}$ & 76 & $\mathrm{~T}$ \\
\hline $\begin{array}{l}\text { Menganalisis faktor } \\
\text { yang dapat } \\
\text { mempengaruhi laju } \\
\text { reaksi berdasarkan data } \\
\text { percobaan }\end{array}$ & 55 & $\mathrm{TT}$ \\
\hline $\begin{array}{l}\text { Menganalisis pengaruh } \\
\text { peningkatan suhu } \\
\text { terhadap laju reaksi. }\end{array}$ & 27 & $\mathrm{TT}$ \\
\hline $\begin{array}{l}\text { Memprediksi laju suatu } \\
\text { reaksi bila beberapa } \\
\text { factor diubah-ubah. }\end{array}$ & 79 & $\mathrm{~T}$ \\
\hline $\begin{array}{l}\text { Menjelaskan pengaruh } \\
\text { penambahan katalis } \\
\text { terhadap laju reaksi. }\end{array}$ & 85 & $\mathrm{~T}$ \\
\hline $\begin{array}{l}\text { Menjelaskan cara } \\
\text { penentuan persamaan } \\
\text { hukum laju reaksi. }\end{array}$ & 76 & $\mathrm{~T}$ \\
\hline $\begin{array}{l}\text { Menentukan orde } \\
\text { reaksi. }\end{array}$ & 94 & $\mathrm{~T}$ \\
\hline $\begin{array}{l}\text { Menentukan laju reaksi } \\
\text { jika konsentrasi } \\
\text { pereaksi diubah-ubah. }\end{array}$ & 82 & $\mathrm{~T}$ \\
\hline $\begin{array}{l}\text { Menentukan laju } \\
\text { sesaat. }\end{array}$ & 94 & $\mathrm{~T}$ \\
\hline & & \\
\hline
\end{tabular}

2. Keterampilan Proses Sains Berdasarkan Gambar 1 dapat diketahui bahwa hasil belajar kognitif proses siswa pada saat pretes dan posttes menunjukkan bahwa $100 \%$ siswa tuntas. Hal ini mengindikasikan bahwa model pembelajaran berbasis inkuiri dapat memberdayakan keterampilan proses sains seluruh siswa. Penyebab keberhasilan model pembelajaran berbasis inkuiri terhadap keterampilan proses sains dikarenakan siswa secara aktif melakukan aktivitas observasi, mengajukan pertanyaan atau masalah, mengumpulkan informasi yang terkait dengan masalah untuk membuat suatu dugaan atau hipotesis, merencanakan penyelidikan, mengunakan alat untuk mengumpulkan data, menganalisis dan menafsirkan data, memberikan penjelasan terhadap data yang diperoleh, membuat kesimpulan serta mengkomunikasikan hasil yang diperoleh dalam proses pembelajarannya (National Research Concil, 2000). Ketuntasan tiap-tiap rincian tugas kinerja dari tes keterampilan proses sains siswa disajikan pada Tabel 2.

Berdasarkan rincian tugas kinerja, terdapat 2 tugas yang tidak tuntas antara lain membuat grafik dari data dan menganalisis data hasil percobaan. Kesalahan yang dijumpai pada pembuatan grafik adalah tidak menuliskan keterangan pada sumbu $\mathrm{x}$ dan y (pada percobaan, sumbu $x$ adalah variabel manipulasi dan sumbu y adalah variabel respon), skala yang dituliskan siswa tidak benar (tidak dimulai dari yang terkecil), tidak menghubungkan titik-titik yang didapat menjadi sebuah garis, Ketiga bentuk kesalahan yang dijumpai dari hasil tes kognitif proses merupakan hal yang 


\begin{abstract}
paling mendasar dalam pembuatan grafik hubungan antara variabel manipulasi dan respon. Menurut Nur (2005) menyatakan bahwa grafik yang baik adalah grafik yang dapat menggambarkan hubungan variabel manipulasi dan variabel kontrol yang benar, skala yang menunjukkan nilai harus mempunyai perbandingan skala yang tetap, serta keterangan pada sumbu $x$ dan sumbu $y$ harus dinyatakan dengan jelas.
\end{abstract}

Tabel 2. Persentase Kentuntasan Tiap-Tiap Rincian Tugas Kinerja (RTK) Tes Keterampilan Proses Siswa

\begin{tabular}{lcc}
\hline $\begin{array}{l}\text { Rincian Tugas Kinerja } \\
\text { (RTK) }\end{array}$ & Ketuntasan $(\%)$ \\
\hline Merumuskan masalah & 97 & $\mathrm{~T}$ \\
\hline Merumuskan hipotesis & 100 & $\mathrm{~T}$ \\
\hline $\begin{array}{l}\text { Merumuskan variabel } \\
\text { manipulasi }\end{array}$ & 100 & $\mathrm{~T}$ \\
\hline Merumuskan variabel & 100 & $\mathrm{~T}$ \\
\hline $\begin{array}{l}\text { Merumuskan variabel } \\
\text { kontrol }\end{array}$ & 100 & $\mathrm{~T}$ \\
\hline $\begin{array}{l}\text { Merumuskan definisi } \\
\text { operasional variabel } \\
\text { manipulasi }\end{array}$ & 100 & $\mathrm{~T}$ \\
\hline $\begin{array}{l}\text { Merumuskan definisi } \\
\text { operasional variabel } \\
\text { respon }\end{array}$ & 100 & $\mathrm{~T}$ \\
\hline $\begin{array}{l}\text { Melaksanakan } \\
\text { eksperimen/percobaan }\end{array}$ & 100 & $\mathrm{~T}$ \\
\hline $\begin{array}{l}\text { Membuat tabel data } \\
\text { hasil eksperimen }\end{array}$ & 100 & $\mathrm{~T}$ \\
\hline $\begin{array}{l}\text { Membuat grafik } \\
\text { berdasarkan tabel data }\end{array}$ & 58 & $\mathrm{TT}$ \\
\hline $\begin{array}{l}\text { Menganalisis } \\
\text { data/grafik hasil } \\
\text { eksperimen }\end{array}$ & 42 & $\mathrm{TT}$ \\
\hline $\begin{array}{l}\text { Merumuskan } \\
\text { kesimpulan }\end{array}$ & 100 & $\mathrm{~T}$ \\
\hline
\end{tabular}

Pada tugas menganalisis data hasil percobaan pada dasarnya siswa dapat menganalisis data hasil percobaan hanya saja siswa tidak dapat memberikan penjelasan data yang dihasilkan dengan teori yang mendasarinya. Hal ini juga dijumpai pada tugas merumuskan hipotesis. Siswa tidak memberikan informasi informasi yang mendasari perumusan hipotesis, akan tetapi siswa dapat memprediksi akibat yang terjadi karena adanya variabel manipulasi. Hal ini disebabkan karena sebelum melaksanakan tes, siswa diminta untuk mempelajari terlebih dahulu materi yang akan diujikan secara individu dan tidak diajarkan pada kegiatan pembelajaran. Hasil ini dapat mengindikasikan bahwa siswa sulit untuk memahami materi yang dipelajari secara individu dan masih perlu bimbingan untuk memahami materi pelajaran.

Kelemahan siswa dalam menganalisis data sebagian besar disebabkan karena pada latihan yang tercantum dalam LKS, siswa dibimbing dengan pertanyaanpertanyaan. Akibatnya ketika siswa diberikan kebebasan dalam menganalisis data, hanya sebagian kecil siswa (44\%) yang berhasil menganalisis data dengan melibatkan semua data yang diperoleh. Hal ini sejalan dengan pendapat Ibrahim (2010) yang menyatakan bahwa untuk melatih keterampilan haruslah melatihkan apa yang akan diujikan dalam proses pembelajarannya. Selain itu, Nur (2005) menyatakan bahwa keterampilan menganalisis adalah keterampilan yang melibatkan 
seluruh data, temuan, atau prosedur kerja yang mempengaruhi hasil serta memberi penjelasan-penjelasan terhadap temuan atau data tersebut dan mengaitkannya dengan teori, konsep, hukum atau prinsip yang berlaku.

3. Keterampilan Sosial Siswa

Keterampilan sosial siswa yang diamati dalam proses pembelajaran terdiri dari tiga indikator, yaitu (a) mengungkapkan ide/pendapat, (b) menjadi pendengar yang baik, dan (c) bekerjasama. Hasil yang diperoleh pada Gambar 1 menunjukkan bahwa $100 \%$ siswa mengalami ketuntasan. Adapun kategori dari tiap-tiap indikator keterampilan sosial siswa dapat dilihat pada Gambar 2. Berdasarkan Gambar 2 dapat ditetahui bahwa tiap-tiap indikator berada pada kategori baik (rentang skor $3<$ skor < 3,75). Hal ini disebabkan karena pada proses penyelidikan (inkuiri), siswa secara aktif membangun pengetahuan lewat interaksinya dengan orang lain. Hal ini ditandai dengan aktifnya siswa dalam bekerjasama menyelesaikan masalah secara bersama-sama, menjadi pendengar ketika mendapat masukan atau informasiinformasi yang berguna dan mengungkapkan ide tau pendapat dalam menanggapi suatu masalah berdasarkan pengetahuan atau informasi yang telah diperoleh.

Hal ini berkesesuaian dengan teori Vygotsky (dalam Slavin, 2006) yang menyatakan bahwa siswa yang kesulitan dalam menyelesaikan tugas yang diberikan membuat siswa belajar dengan cara berinteraksi dengan orang atau siswa lain yang dianggap lebih mampu. Interaksi yang terjadi memungkinkan siswa berpikir untuk saling melengkapi dan menjadi pemahaman bersama, mendengarkan pembicaraan dengan baik dan dapat mempelajari cara orang lain yang berhasil memecahkan masalah (Slavin, 2006).

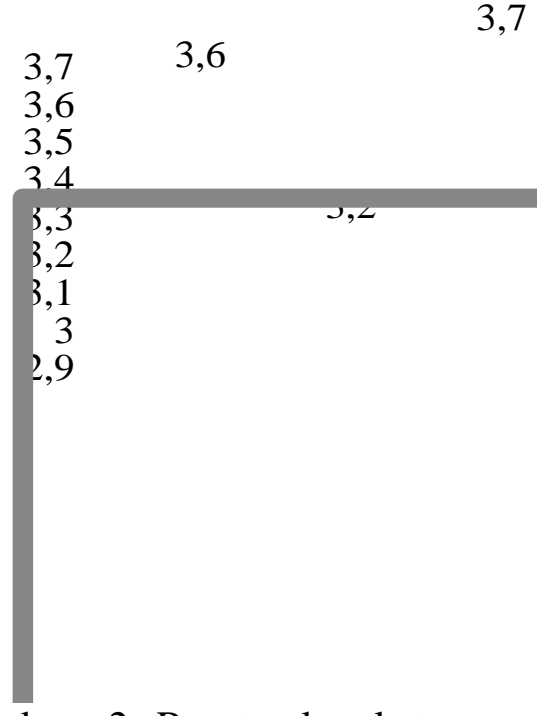

Gambar 2. Rerata skor keterampilan sosial siswa tiap-tiap indikator.

4. Keterampilan Psikomotorik Siswa

Tes hasil belajar psikomotorik siswa yang dinilai adalah keterampilan dalam menggunakan gelas ukur, termometer, pipet tetes dan merangkai pemanas spritus. Hal ini disebabkan karena pada saat siswa melakukan percobaan, banyak alat yang digunakan dan semestinya penggunaan seluruh alat pada saat percobaan juga dinilai. Dari Gambar 1. Diketahui bahwa 
terdapat $87 \%$ siswa yang tuntas. Secara lebih rinci ketuntasan indikator keterampilan psikomotorik siswa disajikan pada Gambar 3.

Keterampilan siswa dalam menggunakan gelas ukur diamati dengan meminta siswa mengambil sejumlah larutan menggunakan gelas ukur dengan volume yang telah ditentukan. Keterampilan siswa dalam menggunakan termometer diamati dengan meminta siswa mengukur suhu suatu larutan yang telah dipanaskan dengan pembakar spritus selama \pm 2 menit dengan menggunakan thermometer.

Keterampilan siswa dalam menggunakan pipet tetes diamati dengan meminta siswa meneteskan beberapa tetes larutan ( 5 sampai 10 tetes) ke dalam tabung reaksi yang telah diisi oleh larutan. Keterampilan siswa dalam merangkai alat pembakar spritus diamati dengan meminta siswa memanaskan suatu larutan yang terdapat dalam gelas kimia dengan menggunakan alat-alat yang diberikan, antara lain pemanas spritus, kaki tiga, dan kawat kasa.

Pada Gambar 3. Dapat diketahui bahwa hasil yang diperoleh pada tes penggunaan pipet tetes tidak sebaik pada tes merangkai alat pembakar spirtus. Hal ini disebabkan karena pada proses pembelajaran, penggunaan pipet tetes tidak mendapat perhatian yang mendalam. Pipet tetes hanya digunakan sebagai alat pendamping dalam melakukan pengukuran volume dengan gelas ukur. Akibatnya perhatian besar

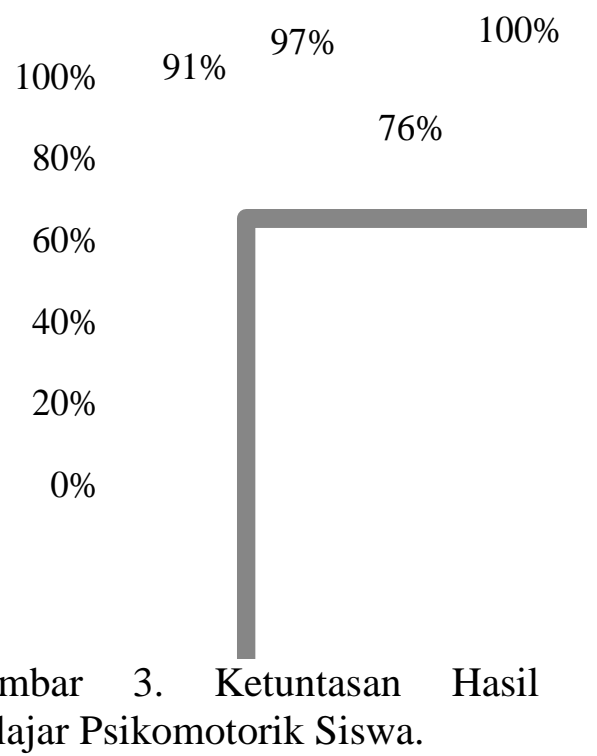

siswa tertuju pada cara penggunaan gelas ukur. Hal ini berbeda dengan merangkai alat pembakar spirtus. Pada proses pembelajarannya, siswa dituntun oleh guru untuk merangkai dengan prosedur yang tepat. Hal ini sesuai dengan pendapat Dave (dalam Ibrahim, M: 2010) yang menyatakan bahwa untuk dapat melakukan sesuatu sesuai dengan prosedur yang tepat, terlebih dahulu diberikan pedoman atau contoh tentang prosedur tersebut.

\section{Simpulan dan Saran}

Dari hasil penelitian yang dilakukan dapat disimpulkan bahwa:

1. Model pembelajaran berbasis inkuiri dapat membuat siswa memahami konsep yang diajarkan, yaitu sebanyak $78 \%$ siswa mengalami ketuntasan dari tes pemahaman konsep pada topik laju reaksi.

2. Model pembelajaran berbasis inkuiri dapat membuat siswa menguasai keterampilan proses 
sains yang ditandai dengan $100 \%$ siswa mengalami ketuntasan.

3. Model pembelajaran berbasis inkuiri dapat mengembangkan keterampilan sosial siswa yang ditandai dengan seluruh indikator keterampilan sosial berada pada kategori baik.

4. Model pembelajaran berbasis inkuiri dapat mengembangkan keterampilan psikomotorik siswa yang ditandai sebesar $87 \%$ siswa dapat menggunakan alat dengan baik antara lain gelas ukur, thermometer, pipet tetes dan pembakar Bunsen.

\section{Daftar Pustaka}

Arends. 2012. Learning to Teach, Ninth Edition. New York: McGraw-Hill.

Balim. 2009. The Effects Of Discovery Learning On Students Success And Inquiry Learning Skills. Eurasian Journal Of Educational Research Vol 35(2) hal 1-20.

Depdiknas. 2006. KTSP Mata Pelajaran Kimia SMA. Jakarta: Departemen Pendidikan Nasional.

Holbrook. 2005. Making Chemistry Teaching Relevant. Journal Chemical Education International Vol 6 (1) hal $132-149$.

Ibrahim, M. 2010. Dasar-Dasar Proses Belajar Mengajar. Surabaya: Unesa University Press.

Jazadi. 2005. Evaluasi dan Pengembangan Proses Belajar-Mengajar di Perguruan Tinggi. Jurnal Ilmu
Pendidikan Vol 12(1) hal 1 17.

Kemendikbud. 2013. Kurikulum 2013, Kompetensi Dasar Jenjang Sekolah Menegah Atas (SMA)/Madrasah Aliyah (MA).

Lestari, Dantes, dan Sadia. 2013. Pengaruh Model Pembelajaran Inkuiri Terbimbing Terhadap Sikap Ilmiah Dan Hasil Belajar IPA. Jurnal Pendidikan Dasar Vol 3(1) hal $17-26$.

National Research Council. 2000. Inquiry And The National Science Education Standards: A Guide for Teaching and Learning. New York: National Academic Press.

Nur. 2005. KeterampilanKeterampilan Sains. Surabaya. Unesa University Press.

Panasan dan Nuangchalerm. 2010. Learning Outcomes of Project-Based And Inquiry Based Learning Activities. Journal Of Social Science Vol 6(2) hal $252-255$.

Permendiknas nomor 41 tahun 2007. Standar Proses Untuk Jenjang Pendidikan Dasar dan Menengah. Jakarta. Menteri Pendidikan Nasional.

Potvin, Riopel, Masson, dan Fournier. 2010. Problem-Centered Learning Vs. TeachingCentered Learning In Science At The Secondary Level: An Analysis of The Dynamics of Doubt. Journal of Applied Research on learning Vol 3(5) hal $1-24$.

Slavin. 2006. Educational Psychology: Theory and 
Keterampilan Proses Sains, Keterampilan Sosial, Keterampilan Psikomotorik 21

Practice Eight Edittion. Wenning. 2004. Levels of Inquiry: Boston: Allyn \& Bacon. Hierarchies of Pedagogical Solso. 2008. Psikologi Kognitif, Edisi Practices and Inquiry Kedelapan (terjemahan). Jakarta: Erlangga. Processes. Illinois State Universirty. 